\title{
Morphine, naloxone and the gonadotrophin surge in ewes
}

\author{
W. D. Currie, I. B. J. K. Joseph and N. C. Rawlings* \\ Veterinary Physiological Sciences, University of Saskatchewan, Saskatoon, \\ Saskatchewan S7N OWO, Canada
}

\begin{abstract}
Summary. Possible endogenous opioid peptide regulation of the preovulatory gonadotrophin surge was examined in ewes during the breeding season. Intact ewes $(n=54)$ were synchronized by treatment for 12 days with intravaginal sponges releasing medroxyprogesterone acetate. Luteinizing hormone $(\mathrm{LH})$ and follicle-stimulating hormone (FSH) secretion prior to and during the gonadotrophin surge were not affected by naloxone $(0.33 \mathrm{mg} / \mathrm{kg}$ body wt per $\mathrm{h})$ administered from the time of medroxyprogesterone acetate withdrawal until $30 \mathrm{~h}$ after the onset of oestrus $(n=6)$. Morphine was administered in 4 patterns: (i) $0.25 \mathrm{mg}$ morphine $/ \mathrm{kg}$ body wt per $\mathrm{h}$ from medroxyprogesterone acetate withdrawal until $30 \mathrm{~h}$ after the onset of oestrus $(n=6)$, (ii) $0.25 \mathrm{mg}$ morphine/ $\mathrm{kg}$ body wt per h from 24 to $48 \mathrm{~h}$ after medroxyprogesterone acetate withdrawal $(n=6)$, (iii) $0.50 \mathrm{mg}$ morphine $/ \mathrm{kg}$ body wt per $\mathrm{h}$ from 24 to $36 \mathrm{~h}$ after medroxyprogesterone acetate withdrawal $(n=6)$ and (iv) $0.50 \mathrm{mg}$ morphine $/ \mathrm{kg}$ body wt per h from 18 to $30 \mathrm{~h}$ after medroxyprogesterone acetate withdrawal $(n=6)$. Oestrus and the gonadotrophin surge were delayed, but not blocked, in all cases of morphine administration $(P<0.05)$. Inconsistent effects of morphine on circulating oestradiol and gonadotrophin concentrations prior to the gonadotrophin surge suggest that the delays are not due to reduced gonadotrophic support of ovarian oestradiol output. Morphine may reduce responsiveness of central behavioural and gonadotrophin surge-generating centres to the oestradiol signal.

The absence of effects of naloxone on gonadotrophin secretion suggest that suppression of LH secretion by opioid peptide activity is reduced after the end of the luteal phase. However, the failure of morphine to block the gonadotrophin surge suggests that reduced opioid peptide activity, at morphine sensitive receptors, is not critical to the surge in ewes.
\end{abstract}

Ke?words: gonadotrophins; morphine; naloxone; oestrus; ewe

\section{Introduction}

In women and rats, endogenous opioid peptide activity may be involved in progesterone and oestradiol suppression of luteinizing hormone $(\mathrm{LH})$ pulse frequency (Blankstein et al., 1981; Robert et al., 1981; Sylvester et al., 1982). A decline in opioid peptide activity in the periovulatory period may allow the preovulatory gonadotrophin surge in these species (Blankstein et al., 1981; Vrbicky et al., 1982; Knuth et al., 1983; Kalra, 1985; Piva \& Martini, 1987). Opiates can suppress ovulation in women (Santen et al., 1975) and rats (Sawyer, 1963) by reducing release of luteinizinghormone-releasing hormone (LHRH) via a receptor-specific action (Packman \& Rothchild, 1976) at the hypothalamus (Sawyer, 1963; Ching, 1983). Blockade of opioid peptide activity in the follicular phase, by naloxone, marginally enhanced the magnitude and advanced the onset of the gonadotrophin surge in rats (Ieiri et al., 1980; Gabriel et al., 1982; Van Vugt et al., 1982).

*Reprint requests. 
In ewes, a major component of progesterone suppression of tonic LH secretion depends upon opioid peptide activity (Brooks et al., 1986; Malven, 1986; Currie \& Rawlings, 1987, 1989; Currie et $a l$, in press). Opioids do not appear to be involved in oestradiol suppression of tonic LH secretion in ewes (Brooks et al., 1986; Yang et al., 1988). Tonic suppression of LH secretion by opioid peptides may be reduced (Brooks et al., 1986), but is detectable during the follicular phase in ewes (Currie \& Rawlings, 1987).

Naloxone administered to ewes during the follicular phase did not affect return to oestrus (Currie \& Rawlings, 1987). Morphine and naloxone did not affect the oestradiol-induced LH surge in anoestrous ewes (Horton \& Clarke, 1988). However, circulating progesterone concentrations remained basal for 14 days following administration of a potent enkephalin analog, FK 33-824, to ewes during the follicular phase (Brooks et al., 1986). FK 33-824 reduced total LH secreted during an oestradiol-stimulated gonadotrophin surge in anoestrous ewes, an effect partially reversed by naloxone (Knight et al., 1990). However, FK 33-824 failed to block or delay oestradiol-induced LH surges in intact or ovariectomized ewes during anoestrus (Knight et al., 1990).

This study tested the hypothesis that reduced endogenous opioid peptide activity in the follicular phase allows the preovulatory gonadotrophin surge in ewes.

\section{Materials and Methods}

\section{Animals}

Fifty-four Suffolk $\times$ Whiteface ewes housed in a drylot were determined to be having regular oestrous cycles using vasectomized rams wearing harnesses with chest crayons (SireSine, Hortico, Laverton North, Vic., Australia). The ewes were between 2 and 5 years of age, with an average weight of $62.0 \pm 1.6 \mathrm{~kg}$ (mean \pm s.e.). The ewes were fed pelleted lucerne ( $1.2 \mathrm{~kg} / \mathrm{ewe}$ per day) with hay, water and mineralized salt provided ad libitum.

\section{Experimental procedures}

Four trials (Exps 1 to 4 ) on 4 occasions at about the midbreeding season were performed indoors, at $13^{\circ} \mathrm{C}$, with lighting conditions simulating natural daylength. Fluorescent $(\sim 80$ footcandles) and incandescent red light $(<5$ footcandles) were used during normal hours of daylight and darkness, respectively.

The ewes were randomly assigned to 9 groups $(n=6 /$ group). Oestrus was synchronized in all of the ewes by treatment for 12 days with intravaginal sponges releasing medroxyprogesterone acetate (Veramix, Tuco Products, Orangeville, Ont.. Canada). One day before medroxyprogesterone acetate withdrawal, the ewes were catheterized in both jugular veins with vinyl tube (i.d. $1.00 \mathrm{~mm}$ o.d. $1.50 \mathrm{~mm}$, SV-70, Dural Plastics and Engineering, Dural, NSW, Australia). Injections were given via the left jugular catheter and samples taken via the right jugular catheter. During trials, each group was housed in a $4 \times 2 \mathrm{~m}$ pen. One ram equipped with a chest crayon was housed with each group of ewes. Rams were switched from one pen to another every $4 \mathrm{~h}$ throughout the experiment. Ewes were checked hourly for evidence of mounting by the rams. As ewes entered oestrus, they were moved to an adjacent pen $(4 \times 4 \mathrm{~m})$.

Morphine was administered at a dose previously observed to maintain suppression of tonic LH pulse frequency in ovariectomized ewes $(0.5 \mathrm{mg} / \mathrm{kg}$ body wt per h over $24 \mathrm{~h}$; Currie \& Rawlings, 1989). Naloxone was administered at a dose previously observed to maintain increased $\mathbf{L H}$ pulse frequency and to increase LH pulse amplitude temporarily in ewes during the luteal phase $(0.5 \mathrm{mg} / \mathrm{kg}$ body wt per h over 6 or $24 \mathrm{~h}$; Currie \& Rawlings, 1987, 1989).

Experiment 1. Medroxyprogesterone acetate sponges were withdrawn on 17 November $(8.5 \mathrm{~h}$ of daylight, sunrise to sunset, Saskatchewan Research Council; mean daily temperature $-7^{\circ} \mathrm{C}$, Environment Canada). Ewes were injected hourly with saline $(0 \cdot 154 \mathrm{M}-\mathrm{NaCl}, 5 \mathrm{ml})$, or naloxone hydrochloride (EI DuPont de Nemours, Garden City, NY, USA) in saline, or morphine sulphate (Ingram \& Bell, Don Mills, Ont, Canada) in saline from the time of medroxyprogesterone acetate withdrawal until $30 \mathrm{~h}$ after the onset of oestrus ( $n=6 /$ group $)$. The mean intervals from medroxyprogesterone withdrawal to the last injection were $79 \pm 4.8,77 \pm 3.7$ and $103 \pm 10.5 \mathrm{~h}$ for the groups treated with saline, naloxone and morphine, respectively. Following an initial injection with a mean dose of $0.67 \mathrm{mg}$ naloxone or $0.62 \mathrm{mg}$ morphine $/ \mathrm{kg}$ body wt, the mean hourly dose given to each ewe was $0.33 \mathrm{mg}$ naloxone or $0.25 \mathrm{mg}$ morphine $/ \mathrm{kg}$ body wt. The design was intended to maintain naloxone or morphine in circulation throughout the follicular phase, oestrus and the gonadotrophin surge (Martin, 1984). Blood samples $(4 \mathrm{ml})$ were collected hourly prior to each injection and at 6-h intervals for $72 \mathrm{~h}$ following the last injection of each ewe.

Experiment 2. Medroxyprogesterone acetate sponges were withdrawn on 5 December $(7.9 \mathrm{~h}$ of daylight; mean daily temperature $-12^{\circ} \mathrm{C}$ ). Ewes were injected hourly with saline or morphine in saline, at the doses used in Exp. 1, from 24 to $48 \mathrm{~h}$ after medroxyprogesterone acetate withdrawal ( $n=6 /$ group). The design was intended to (i) allow 
clearance of circulating medroxyprogesterone and onset of rapid follicular maturation, prior to the appearance of morphine in circulation and (ii) allow clearance of circulating morphine to begin prior to the normal time of occurrence of the gonadotrophin surge. Blood samples were collected hourly beginning $24 \mathrm{~h}$ after medroxyprogesterone acetate withdrawal or at the onset of oestrus, if oestrus began sooner than this. Sampling continued until $30 \mathrm{~h}$ after the onset of oestrus in each ewe.

Experiment 3. Medroxyprogesterone acetate sponges were withdrawn on 19 December $(7 \cdot 7$ h of daylight; mean daily temperature $-15^{\circ} \mathrm{C}$ ). Ewes were injected hourly with saline or morphine in saline, from 24 to $36 \mathrm{~h}$ after medroxyprogesterone acetate withdrawal ( $n=6 /$ group). Following an initial injection of $1 \cdot 25 \mathrm{mg}$ morphine/ $\mathrm{kg}$ body wt, the mean hourly dose given to each ewe was $0.50 \mathrm{mg}$ morphine $/ \mathrm{kg}$ body wt. The design was intended to (i) restrict circulating morphine to a reduced portion of the latter half of the follicular phase, further from the normal time of occurrence of the gonadotrophin surge and (ii) maintain the total dose of morphine administered the same as in Exp. 2. Blood samples were collected houriy as in Exp. 2.

Experiment 4. Medroxyprogesterone acetate sponges were withdrawn on 2 January $(7.8 \mathrm{~h}$ of daylight; mean daily temperature $-17^{\circ} \mathrm{C}$ ). Ewes were injected hourly with saline or morphine in saline, as in Exp. 3, from 18 to $30 \mathrm{~h}$ after medroxyprogesterone acetate withdrawal ( $n=6 /$ group). The design was intended to (i) restrict morphine to a portion of the follicular phase, further yet from the normal time of occurrence of the gonadotrophin surge and (ii) maintain the total dose of morphine administered the same as in Exps 2 and 3. Blood samples were collected hourly as in Exps 2 and 3 .

\section{Radioimmunoassays}

Blood samples were allowed to clot for $6 \mathrm{~h}$ at $20^{\circ} \mathrm{C}$, clots were removed and serum was centrifuged at $1500 \times g$ for 15 min. Serum was stored at $-20^{\circ} \mathrm{C}$ until analysed. All samples were analysed for LH and follicle-stimulating hormone (FSH). Every fourth hourly sample and all samples collected at 6-h intervals in Exp. 1 were analysed for progesterone. Samples collected from $24 \mathrm{~h}$ before the onset until the onset of the gonadotrophin surge were analysed for oestradiol.

$\boldsymbol{L H}$ and $\boldsymbol{F S H}$. Serum LH and FSH concentrations were determined by validated radioimmunoassays (Rawlings et al., 1984; Currie \& Rawlings, 1989) and are expressed in terms of NIAMDD-oLH and NIAMDD-oFSH-RP-1, respectively. Sensitivities of the assays, expressed as the lowest standards different from zero by unpaired $t$ test, were $0.1 \mathrm{ng} \mathrm{LH} / \mathrm{ml}$ serum and $0.2 \mathrm{ng} \mathrm{FSH} / \mathrm{ml}$ serum $(P<0 \cdot 05)$. Intra- and interassay coefficients of variation (CVs), respectively, for the LH assay were 4.6 and $6.9 \%$ (mean $=2.4 \mathrm{ng} / \mathrm{ml}$ serum $), 6.0$ and $8.9 \%(\mathrm{mean}=1.6 \mathrm{ng} / \mathrm{ml} \mathrm{serum})$ and 6.6 and $11 \%$ (mean $=0.5 \mathrm{ng} / \mathrm{ml}$ serum). Intra- and interassay CVs, respectively, for FSH were $4 \cdot 1$ and $5 \cdot 2 \%$ (mean $=9.0 \mathrm{ng} / \mathrm{ml}$ serum) and 10 and $13 \%$ (mean $=0.65 \mathrm{ng} / \mathrm{ml}$ serum). Samples with LH or FSH concentrations exceeding the highest standards in the assays $(8 \mathrm{ng} / \mathrm{ml})$ were re-analysed at dilutions of $1: 2,1: 4,1: 8$ and 1:16.

Oestradiol. The oestradiol assay has been validated (Rawlings et al., 1984). Intra- and interassay CVs, respectively, for the oestradiol assay were 11 and $16 \%$ (mean $=6 \mathrm{pg} / \mathrm{ml}$ serum), 10 and $17 \%$ (mean $=8 \mathrm{pg} / \mathrm{ml} \mathrm{serum}$ ), 8 and $14 \%$ $($ mean $=10 \mathrm{pg} / \mathrm{ml} \mathrm{serum})$ and 12 and $14 \%$ (mean $=13 \mathrm{pg} / \mathrm{ml}$ serum). Sensitivity of the assay, by unpaired $t$ test, was $1 \mathrm{pg} / \mathrm{ml} \operatorname{serum}(P<0.05)$.

Progesterone. The progesterone assay has been validated (Currie \& Rawlings, 1989). Intra- and interassay CVs, respectively, for the progesterone assay were 9.9 and $19 \%$ (mean $=1.0 \mathrm{ng} / \mathrm{ml}$ serum) and 8.5 and $15 \%($ mean $=$ $2.2 \mathrm{ng} / \mathrm{ml}$ serum). Sensitivity of the assay, by unpaired $t$ test, was $0 \cdot 1 \mathrm{ng} / \mathrm{ml}$ serum $(P<0 \cdot 05)$. Medroxyprogesterone acetate does not cross-react with the primary antisera used in the assay.

\section{Gonadotrophin surge criteria}

A gonadotrophin surge was considered as an increase of serum gonadotrophin concentrations lasting at least $6 \mathrm{~h}$ and at least 10 times greater than mean $\mathrm{LH}$ concentration and twice the mean FSH concentration observed in the previous samples. The onset and conclusion of the surge in each ewe were considered the times of the first and last samples, respectively, in the surge that were $>0.8$ standard deviations above mean follicular phase LH or FSH concentrations, for the treatment group to which each ewe belonged. LH and FSH surge magnitudes are reported as means of absolute sample concentrations.

\section{Statistical analysis}

Effects of morphine treatment, period (Exps 1 to 4) and morphine treatment $\times$ period interaction on (i) time from progesterone withdrawal to onset of oestrus and to the gonadotrophin surge peak, (ii) magnitude and duration of LH and FSH surges and (iii) mean serum LH, FSH and oestradiol concentrations over $24 \mathrm{~h}$ prior to the onset of the gonadotrophin surge were examined by two-way analysis of variance (True Epistat, 3rd edition, Epistat Services, Richardson, Texas, USA). Newman-Keuls multiple comparison test was used for separation of means following detection of interactions. Effects of naloxone were examined for the same variables by one-way analysis of variance. 
The $24 \mathrm{~h}$ prior to the onset of the surge was used for comparison of tonic LH, FSH and oestradiol concentrations during the follicular phase as hourly data were complete for all but one ewe for this period.

\section{Results}

\section{Experiments 1 to 4}

Period effects were not detected for any variable examined. LH and FSH surge peaks were synchronous to within $1 \mathrm{~h}$ in each ewe.

Table 1. Effects of naloxone or morphine on mean serum luteinizing hormone ( $\mathrm{LH})$, follicle-stimulating hormone (FSH) and oestradiol concentrations over $24 \mathrm{~h}$ before the gonadotrophin-surge in ewes, following treatment with medroxyprogesterone acetate

\begin{tabular}{|c|c|c|c|}
\hline Treatment & $\begin{array}{c}\text { Mean oestradiol } \\
(\mathrm{pg} / \mathrm{ml} \text { serum) }\end{array}$ & $\begin{array}{c}\text { Mean LH } \\
\text { (ng/ml serum) }\end{array}$ & $\begin{array}{c}\text { Mean FSH } \\
(\mathrm{ng} / \mathrm{ml} \text { serum) }\end{array}$ \\
\hline Control $^{1}$ & $8 \cdot 4 \pm 0.8$ & $0.6 \pm 0.1$ & $1 \cdot 1 \pm 0.2$ \\
\hline Naloxone ${ }^{1}$ & $9.0 \pm 0.3$ & $0.4 \pm 0.1$ & $1 \cdot 3 \pm 0.4$ \\
\hline Morphine & $5 \cdot 0 \pm 0 \cdot 3^{*}$ & $0.6 \pm 0.1$ & $1 \cdot 2 \pm 0.2$ \\
\hline Control $^{2}$ & $8.6 \pm 0.9$ & $0.6 \pm 0.1$ & $1 \cdot 2 \pm 0 \cdot 1$ \\
\hline Morphine $^{2}$ & $7 \cdot 5 \pm 1 \cdot 2$ & $0.3 \pm 0.1^{*}$ & $1.3 \pm 0.2$ \\
\hline Control $^{3}$ & $7 \cdot 8 \pm 1.0$ & $0.5 \pm 0.1$ & $1 \cdot 2 \pm 0 \cdot 2$ \\
\hline Morphine $^{3}$ & $7.4 \pm 0.8$ & $0.5 \pm 0.1$ & $1.4 \pm 0.2$ \\
\hline Control $^{4}$ & $7 \cdot 6 \pm 0.5$ & $0.6 \pm 0.1$ & $1 \cdot 0 \pm 0.2$ \\
\hline Morphine ${ }^{4}$ & $7 \cdot 1 \pm 1 \cdot 2$ & $0.3 \pm 0.1^{*}$ & $1 \cdot 1 \pm 0.1$ \\
\hline
\end{tabular}

${ }^{1}$ Naloxone $(0.33 \mathrm{mg} / \mathrm{kg}$ body wt per $\mathrm{h})$ or morphine $(0.25 \mathrm{mg} / \mathrm{kg}$ body wt per $\mathrm{h})$ from medroxyprogesterone acetate withdrawal until $30 \mathrm{~h}$ after onset of oestrus.

${ }^{2}$ Morphine $(0.25 \mathrm{mg} / \mathrm{kg}$ body wt per $\mathrm{h})$ from 24 to $48 \mathrm{~h}$ after medroxyprogesterone acetate withdrawal.

${ }^{3}$ Morphine $(0.50 \mathrm{mg} / \mathrm{kg}$ body wt per $\mathrm{h})$ from 24 to $36 \mathrm{~h}$ after medroxyprogesterone acetate withdrawal.

${ }^{4}$ Morphine $(0.50 \mathrm{mg} / \mathrm{kg}$ body wt per $\mathrm{h})$ from 18 to $30 \mathrm{~h}$ after medroxyprogesterone acetate withdrawal.

Values are means \pm s.e.

* Mean differs from its control mean $(P<0.05)$.

\section{Experiment 1}

No variables examined were affected by naloxone $P>0.05$, Tables 1 and 2). Tonic $\mathrm{LH}$ and FSH concentrations during the follicular phase were not affected $(P>0.05)$, but oestradiol was reduced in the morphine-treated group $(P<0.05$, Table 1). Onset of oestrus and the gonadotrophin surge were delayed in the morphine treated group $(P<0.05$, Table 2$)$. Circulating progesterone concentrations were within the sensitivity of the assay, in all groups, following medroxyprogesterone withdrawal (Fig. 1). Straight lines were fitted to progesterone data from each group from the time mean circulating progesterone concentration increased beyond assay sensitivity $(96,102$ and $110 \mathrm{~h}$ after medroxyprogesterone withdrawal in control, naloxone-treated and morphine-treated ewes, respectively) until $150 \mathrm{~h}$ after medroxyprogesterone withdrawal. During this period, circulating progesterone concentrations increased at $\sim 10 \mathrm{pg}$ progesterone $/ \mathrm{ml}$ serum per $\mathrm{h}$ in each group.

\section{Experiment 2}

Tonic FSH and oestradiol concentrations during the follicular phase were not affected $(P>0.05)$, but LH was reduced in the morphine-treated group $(P<0.05$, Table 1$)$. Onset of 
Table 2. Effects of naloxone or morphine on the time from medroxyprogesterone acetate withdrawal to oestrus $\left(\mathrm{P}_{4}-\mathrm{E}\right)$ and to the gonadotrophin surge $\left(\mathrm{P}_{4}-\mathrm{S}\right)$ and on the magnitude $\left(\mathrm{LH}_{\text {mag }}\right.$ and $\left.\mathrm{FSH}_{\text {mag }}\right)$ and duration $\left(\mathrm{LH}_{\text {dur }}\right.$ and $\left.\mathrm{FSH}_{\text {dur }}\right)$ of the surge in luteinizing hormone $(\mathrm{LH})$ and follicle-stimulating hormone $(\mathrm{FSH})$ in ewes, following treatment with medroxyprogesterone acetate

\begin{tabular}{|c|c|c|c|c|c|c|}
\hline Treatment & $\begin{array}{l}P_{4}-E \\
(h)\end{array}$ & $\begin{array}{l}\mathrm{P}_{4}-\mathrm{S} \\
\text { (h) }\end{array}$ & $\begin{array}{l}\mathrm{LH}_{\mathrm{mag}} \\
\quad(\mathrm{ng} / \mathrm{m}\end{array}$ & $\underset{\text { erum) }}{\mathrm{FSH}_{\text {mag }}}$ & $\begin{array}{c}\mathrm{LH}_{\text {dur }} \\
\text { (h) }\end{array}$ & $\begin{array}{c}\mathrm{FSH}_{\text {dur }} \\
\text { (h) }\end{array}$ \\
\hline $\begin{array}{l}\text { Control }^{1} \\
\text { Naloxone }^{1} \\
\text { Morphine }^{1}\end{array}$ & $\begin{array}{l}49 \pm 4.8 \\
47 \pm 3 \cdot 7 \\
73 \pm 10 \cdot 5^{*}\end{array}$ & $\begin{array}{l}56 \pm 5 \cdot 4 \\
52 \pm 4 \cdot 4 \\
70 \pm 9 \cdot 5^{*}\end{array}$ & $\begin{array}{l}30 \pm 3 \cdot 2 \\
30 \pm 3 \cdot 6 \\
38 \pm 5 \cdot 4\end{array}$ & $\begin{array}{l}6.5 \pm 0.8 \\
6.3 \pm 1 \cdot 2 \\
6.8 \pm 0.4\end{array}$ & $\begin{array}{l}16 \pm 0.8 \\
14 \pm 0 \cdot 9 \\
18 \pm 3 \cdot 4\end{array}$ & $\begin{array}{l}10 \pm 0.5 \\
11 \pm 1.5 \\
12 \pm 1 \cdot 3\end{array}$ \\
\hline $\begin{array}{l}\text { Control }^{2} \\
\text { Morphine }^{2}\end{array}$ & $\begin{array}{ll}43 \pm & 3 \cdot 7 \\
58 \pm & 6 \cdot 2^{*}\end{array}$ & $\begin{array}{l}53 \pm 3 \cdot 5 \\
67 \pm 3 \cdot 9^{*}\end{array}$ & $\begin{array}{l}31 \pm 1 \cdot 9 \\
28 \pm 2 \cdot 4\end{array}$ & $\begin{array}{l}7.1 \pm 0.9 \\
6.4 \pm 1.5\end{array}$ & $\begin{array}{l}15 \pm 0.5 \\
13 \pm 1.6\end{array}$ & $\begin{array}{l}12 \pm 0.9 \\
11 \pm 1.0\end{array}$ \\
\hline $\begin{array}{l}\text { Control }^{3} \\
\text { Morphine }^{3}\end{array}$ & $\begin{array}{l}45 \pm 3 \cdot 7 \\
55 \pm 5 \cdot 2^{*}\end{array}$ & $\begin{array}{l}52 \pm 4 \cdot 2 \\
65 \pm 3 \cdot 8^{*}\end{array}$ & $\begin{array}{l}30 \pm 1 \cdot 8 \\
27 \pm 4 \cdot 3\end{array}$ & $\begin{array}{l}6 \cdot 1 \pm 1 \cdot 1 \\
7 \cdot 1 \pm 0.7\end{array}$ & $\begin{array}{l}15 \pm 0.7 \\
14 \pm 0.8\end{array}$ & $\begin{array}{l}11 \pm 1 \cdot 5 \\
10 \pm 0 \cdot 9\end{array}$ \\
\hline $\begin{array}{l}\text { Control }^{4} \\
\text { Morphine }^{4}\end{array}$ & $\begin{array}{ll}48 \pm & 3 \cdot 7 \\
67 \pm & 3 \cdot 8^{*}\end{array}$ & $\begin{array}{l}53 \pm 2.9 \\
65 \pm 5 \cdot 4^{*}\end{array}$ & $\begin{array}{l}29 \pm 1 \cdot 2 \\
37 \pm 2 \cdot 4^{*}\end{array}$ & $\begin{array}{l}6.6 \pm 0.6 \\
5.7 \pm 0.4\end{array}$ & $\begin{array}{l}17 \pm 1.3 \\
16 \pm 1.9\end{array}$ & $\begin{array}{l}12 \pm 1 \cdot 0 \\
11 \pm 1 \cdot 0\end{array}$ \\
\hline
\end{tabular}

'Naloxone $(0.33 \mathrm{mg} / \mathrm{kg}$ body wt per $\mathrm{h})$ or morphine $(0.25 \mathrm{mg} / \mathrm{kg}$ body wt per $\mathrm{h})$ from medroxyprogesterone acetate withdrawal until $30 \mathrm{~h}$ after onset of oestrus.

${ }^{2}$ Morphine $(0.25 \mathrm{mg} / \mathrm{kg}$ body wt per $\mathrm{h})$ from 24 to $48 \mathrm{~h}$ after medroxyprogesterone acetate withdrawal.

${ }^{3}$ Morphine $(0.50 \mathrm{mg} / \mathrm{kg}$ body wt per $\mathrm{h})$ from 24 to $36 \mathrm{~h}$ after medroxyprogesterone acetate withdrawal.

${ }^{4}$ Morphine $(0.50 \mathrm{mg} / \mathrm{kg}$ body wt per h) from 18 to $30 \mathrm{~h}$ after medroxyprogesterone acetate withdrawal.

Values are means \pm s.e.

*Mean differs from its control mean $(P<0.05)$.

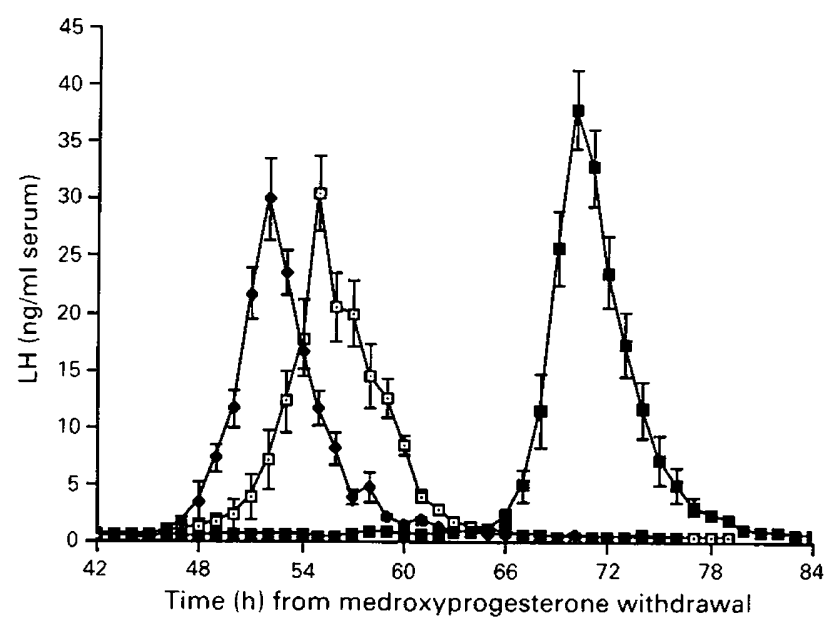

Fig. 1. Circulating luteinizing hormone $(\mathrm{LH})$ concentrations during the gonadotrophin surges in ewes injected with saline $(5 \mathrm{ml} / \mathrm{h})(\square)$, naloxone $(0.33 \mathrm{mg} / \mathrm{kg}$ body wt per $\mathrm{h})(\diamond)$ or morphine $(0.25 \mathrm{mg} / \mathrm{kg}$ body wt per h) (ם) from medroxyprogesterone acetate withdrawal until $30 \mathrm{~h}$ after onset of oestrus (Exp. 1, $n=6 /$ group). Values are means \pm s.e. 
oestrus and the gonadotrophin surge were delayed in the morphine-treated group $(P<0.05$, Table 2).

\section{Experiment 3}

Tonic LH, FSH and oestradiol concentrations during the follicular phase were not affected by morphine $(P>0 \cdot 05$, Table 1). Onset of oestrus and the gonadotrophin surge were delayed in the morphine-treated group $(P<0.05$, Table 2$)$.

\section{Experiment 4}

Tonic FSH and oestradiol concentrations during the follicular phase were not affected $(P>0.05)$, but LH concentrations were reduced in the morphine-treated group $(P<0.05$, Table 1). Onset of oestrus and the gonadotrophin surge were delayed in the morphine-treated group $(P<0.05$, Table 2$)$. The magnitude of the $\mathrm{LH}$ surge was greater in the morphine-treated group $(P<0 \cdot 05$, Table 2$)$.

\section{Discussion}

A lack of effects of naloxone suggested that gonadotrophin secretion is not tonically suppressed by opioid peptide activity at naloxone-sensitive receptors during the follicular phase or gonadotrophin surge (Tables 1 and 2). A reduction in opioid-dependent progesterone suppression of LH secretion at the conclusion of the luteal phase (Brooks et al., 1986; Currie \& Rawlings, 1987) may be one mechanism increasing tonic LHRH and LH secretory activity during the follicular phase in ewes.

The effects of morphine on tonic follicular phase LH and oestradiol concentrations were not consistent. Oestradiol was reduced only in ewes treated with morphine throughout the follicular phase, while circulating LH concentrations prior to the gonadotrophin surge were reduced only in ewes treated with morphine from 24 to $48 \mathrm{~h}$ (Exp. 2), and from 18 to $30 \mathrm{~h}$ (Exp. 4) after medroxyprogesterone withdrawal. It was suggested that oestrus was delayed through suppression of LH secretion in sows treated with morphine 3 times/day for 5 days after weaning (Armstrong et al., 1988). The hourly samples obtained here were too infrequent to detect LH pulses. However, morphine neither affected FSH nor consistently reduced mean LH concentrations. It was concluded that reduced gonadotrophic support of oestradiol output was not the likely cause of the observed delays to oestrus and the gonadotrophin surge in morphine-treated ewes. Morphine may reduce the responsiveness of central behavioural and gonadotrophin-surge-generating centres to the oestradiol signal. The onset of oestrus preceded detection of the gonadotrophin surge peak in all control groups, as expected (Martin, 1984). Onset of oestrus followed the peak of the gonadotrophin surge in 2 morphine-treated groups (Exps 1 and 4). This suggested that morphine may differentially affect the responsiveness of the behavioural and gonadotrophin-surge-generating centres to the oestradiol signal.

The occurrence of the gonadotrophin surge and the rise in circulating progesterone following the gonadotrophin surge indicates that morphine does not block ovulation. This suggests that blockade of oestradiol positive feedback on gonadotrophin secretion, by luteal progesterone concentrations, may not depend upon opioid activity at morphine-sensitive receptors. Opiate activity may delay oestrus and the gonadotrophin surge by weakly suppressing activity of central pathways which are potently suppressed by progesterone, or by suppressing the activity of alternate stimulatory pathways. The effects of morphine on phasic gonadotrophin secretion contrast with the effects of morphine and progesterone on tonic LH secretion. Morphine infusion, in the dose range used in this study, and progesterone replacement, at luteal concentrations, suppress tonic $\mathrm{LH}$ secretion to approximately the same degree in ovariectomized ewes during the breeding season (Currie et al., 1988 , in press). 
It was reported that luteal progesterone was absent for 14 days following a $12 \mathrm{~h}$ infusion of FK 33-824 to ewes in the follicular phase (Brooks et al., 1986). This lengthy delay in ovulation (Brooks et al., 1986) contrasts with the effects of morphine observed in this study. This suggests that a potential opioid-dependent component of progesterone-blockade of the gonadotrophin surge depends upon opioid activity at opioid receptor types not sensitive to morphine. Multiple opioid receptor types are suspected (Khatchaturian et al., 1985). Morphine and naloxone did not affect oestradiol-induced LH surges in anoestrous ewes (Horton \& Clarke, 1988). Similarly, FK 33-824 failed to delay oestradiol-stimulated gonadotrophin surges in intact or ovariectomized ewes during the anoestrum (Knight et al., 1990). Examination of opiate effects on the gonadotrophin surge in ewes appears to be affected by the season, recent ovarian steroid exposure and the opiate analog used. Results of this experiment suggest that opiate activity at morphine-sensitive receptors will delay, but not block, periovulatory events.

The cause of the increased magnitude of the LH surge in one group of morphine-treated ewes remains equivocal (Exp. 4, Table 2). The lack of effects of morphine on LH-surge magnitude in other groups suggested that the observed increase was not simply due to increased time for storage of gonadotrophins prior to the surge.

In conclusion, the reduction in tonic suppression of $\mathrm{LH}$ secretion by opioid peptides during the follicular phase suggests that withdrawal of opioid peptide activity following the luteal phase may allow the gonadotrophin surge to occur. The ability of morphine to delay the preovulatory gonadotrophin surge supports this conclusion. However, the absence of opioid peptide activity at morphine-sensitive receptors may not be critical to either oestrus or the preovulatory gonadotrophin surge in ewes.

This study was funded by NSERC. Naloxone was provided by DuPont. Standards for LH and FSH assays were provided by NIAMDD. Bovine LH for iodination was provided by L. E. Reichert, Jr. Technical assistance was provided by S. Cook. Care of animals was provided by M. Buckley and staff.

\section{References}

Armstrong, J.D., Kraeling, R.R. \& Britt, J.H. (1988) Morphine suppresses luteinizing hormone concentrations in transiently weaned sows and delays onset of estrus after weaning. J. Anim. Sci. 66, 2216 2223 .

Blankstein, J., Reyes, F.I., Winter, J.S.D. \& Faiman, C. (1981) Endorphins and the regulation of the human menstrual cycle. Clin. Endocr. 14, 287 -294.

Brooks, A.N., Lamming, G.E., Lees, P.D. \& Haynes, N.B. (1986) Opioid modulation of LH secretion in the ewe. J. Reprod. Fert. 76, 693-708.

Ching, M. (1983) Morphine suppresses the proestrous surge of $\mathrm{GnRH}$ in pituitary portal plasma of rats. Endocrinolog. 112, 22092211 .

Currie, W.D., Cook, S.J. \& Rawlings, N.C. (in press) LH secretion in ovariectomized ewes: Effects of morphine and ovarian steroid interactions with naloxone during the breeding season and anestrum. Can. J. Anim. Sci.

Currie, W.D. \& Rawlings, N.C. (1987) Naloxone enhances LH but not FSH during various phases of the estrous cycle in the ewe. Life Sci. 41, 1207-1214.

Currie, W.D. \& Rawlings, N.C. (1989) Prolonged infusion of morphine and naloxone in the ewe: fluctuation in responsiveness of $\mathrm{LH}$ and lack of responsiveness of FSH. J. Reprod. Fert. 86, 359-366.

Currie, W.D., Rawlings, N.C. \& Cook, S.J. (1988) Divergent response of $\mathrm{LH}$ to morphine in the ovariectom- ized ewe. Ilth Int. Congr. Reprod. Art. Insem., Dublin, 2, 19.

Gabriel, S.M., Simpkins, J.W. \& Kalra, S.P. (1982) Participation of opioid neurons in LH secretion in cyclic, ovariectomized and steroid treated rats. $66 \mathrm{th} A n n$. Meet. Fed. Amer. Soc. Exp. Biol., New Orleans, p. 984 .

Horton, R.J.E. \& Clarke, I.J. (1988) Lack of an effect of morphine or naloxone on the oestrogen-induced LH surge in anoestrous ewes. J. Endocr. 119, 89-93.

leiri, T., Chen, H.T., Campbell, G.A. \& Meites, J. (1980) Effects of naloxone and morphine on the proestrous surge of prolactin and gonadotropins in the rat. Endocrinology 106, 1568-1570.

Kalra, S.P. (1985) Neural circuits involved in the control of LHRH secretion: A model for estrous cycle regulation. J. Ster. Biochem. 23, 733-742.

Khatchaturian, H., Lewis, M.E., Schafer, M.K.H. \& Watson, S.J. (1985) Anatomy of the CNS opioid systems. Trends NeuroSci. 222, 111-119.

Knight, P.G., Stansfield, S.C. \& Cunningham, F.J. (1990) Attenuation by an opioid agonist of the oestradiolinduced $\mathrm{LH}$ surge in anoestrous ewes and its reversal by naloxone. Dom. Anim. Endocr. 7, 165-172.

Knuth, U.A., Sikand, G.S., Casaneuva, F.F., Havlicek, V. \& Friesen, H.G. (1983) Changes in beta-endorphin content in discrete areas of the hypothalamus 
throughout proestrus and diestrus in the rat. Life Sci. 33, $1443-1450$.

Malven, P.V. (1986) Inhibition of pituitary LH release resulting from endogenous opioid peptides. Dom. Anim. Endocr. 3, 135-144.

Martin, G.B. (1984) Factors affecting the secretion of luteinizing hormone in the ewe. Biol. Rev. 59, 1-87.

Packman, P.M. \& Rothchild, J.A. (1976) Morphine inhibition of ovulation: reversal by naloxone. Endocrinology 99, 7-10.

Piva, F. \& Martini, L. (1987) Role of endorphins and other opioids in the control of anterior pituitary functions. Horm. Res. 25, $238-239$.

Rawlings, N.C., Jeffcoate, I.A. \& Rieger, D.L. (1984) The influence of estradiol-17 $\beta$ and progesterone on peripheral serum concentrations of luteinizing hormone and follicle stimulating hormone in the ovariectomized ewe. Theriogenology 22, 473-488.

Robert, J.F., Quigley, M.E. \& Yen, S.S.C. (1981) Endogenous opiates modulate pulsatile luteinizing hormone release in humans. J. Clin. Endocr. Metab. 52, 583-585.

Santen, R.J., Sofsky, J., Bilic, N. \& Lippert, R. (1975) Mechanism of action of narcotics in the production of menstrual dysfunction in women. Fert. Steril. 26, 538-548.

Sawyer, C.H. (1963) Discussion: neuroendocrine blocking agents and gonadotrophin release. In Advances in Neuroendocrinology, p. 444. Ed. A. V. Nalbandov. Univ. of Illinois Press, Urbana.

Sylvester, P.W., Van Vugt, D.A., Aylsworth, C.A., Hanson, E.A. \& Meites, J. (1982) Effects of morphine and naloxone on inhibition by ovarian hormones of pulsatile release of $\mathrm{LH}$ in ovariectomized rats. Neuroendocrinology 34, 269-273.

Van Vugt, D.A., Sylvester, P.W., Aylsworth, C.F.\& Meites, J. (1982) Counteraction of gonadal steroid inhibition of luteinizing hormone release by naloxone. Neuroendocrinology 34, 274-278.

Vrbicky, K.W., Baumstark, J.S., Wells, I.C., Hilgers, T.W., Kable, W.T. \& Elias, C.J. (1982) Evidence for the involvement of $\beta$-endorphin in the human menstrual cycle. Fert. Steril. 38, 701-704.

Yang, K., Haynes, N.B., Lamming, G.E. \& Brooks, A.N. (1988) Ovarian steroid hormone involvement in endogenous opioid modulation of $\mathrm{LH}$ secretion in mature ewes during the breeding and non-breeding seasons. J. Reprod. Fert. 83: 129-139.

Received 28 August 1990 